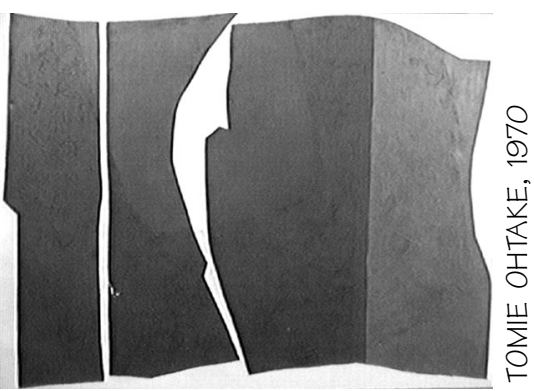

\title{
Inovações pedagógicas: \\ tempos de silêncios e possibilidades de produção
}

Teaching innovation: times of quiet and the ability to produce

PALAVRAS-CHAVE:

Enfermagem;

Informática; tecnologia

educacional.

KEY WORDS: Nursing;

Informatic; educational

technology.

PALABRAS CLAVE:

Enfermería; Informática;

tecnología educativa.

Uma dimensão que pode afetar profundamente os saberes dos educadores está ligada ao reforço da condição de visão única, tão caro à ciência moderna e reforçada pelos dispositivos políticos da produtividade. Trata-se de um processo de padronização, como se houvesse uma única forma de conhecimento e uma só alternativa de formação. Como lembra Santos (2002), o dilema consiste em que a validação de uma só forma de conhecimento provoca a cegueira epistemológica e valorativa, destruindo as relações entre os objetos e, nessa trajetória, eliminando as demais formas alternativas de conhecimentos. "O reverso da força da visão única é a capacidade para reconhecer visões alternativas" (p.241). O autor, sabiamente, alerta que esse fenômeno pode redundar num epistemicídio, afirmando que "a destruição de formas alternativas de conhecimento não é um artefato sem conseqüências, antes implica a destruição de práticas sociais e desqualificação de agentes sociais que operam de acordo com o conhecimento em causa" (p.242).

\footnotetext{
${ }^{1}$ Professora, Programa de Pós-Graduação em Educação, Universidade Vale do Rio dos Sinos, Unisinos, RS. <mabel@conesul.com.br>
} 


\section{DEBATES}

Ainda frágeis e minoritárias, as inovações que procuramos afirmar no campo acadêmico enfrentam toda a dificuldade decorrente da presença paradigmática dominante. Já na sua geração carregam o ônus da complexidade da iniciativa. Santos (2002) afirma que a "luta paradigmática é, no seu conjunto, altamente arriscada" (p.344), pois exige uma subjetividade emergente que envolve ruptura epistemológica e societal. Para o autor, formas alternativas de conhecimento geram práticas alternativas e viceversa, perpassando o conceito de subjetividade, que constitui o grande mediador entre conhecimento e práticas.

As inovações que adivinhamos próximas se materializam pelo reconhecimento de formas alternativas de saberes e experiências, nas quais imbricam objetividade e subjetividade, senso comum e ciência, teoria e prática, cultura e natureza, anulando dicotomias e procurando gerar novos conhecimentos mediante novas práticas.

Essas inovações, entendidas como ruptura paradigmática, exigem dos professores reconfiguração de saberes e favorecem o reconhecimento da necessidade de trabalhar no sentido de transformar, como refere Santos, a "inquietude" em energia emancipatória (p.346). Envolvem o reconhecimento da diferença e implicam, em grande medida, um trabalho que consiste, especialmente, em gerir relações sociais com seus alunos. $\mathrm{Na}$ afirmativa de Tardif (2002), é "por isso que a pedagogia é feita de dilemas e tensões, de negociações e estratégias de interação". Para o autor, "ensinar é fazer escolhas, constantemente, em plena interação com os alunos" (p.132). Essas escolhas são dependentes da experiência dos atores, do contexto de tempo e território do ensino, das convicções e crenças que suportam o trabalho e, conseqüentemente, de situações que, sendo únicas, exigem respostas diferenciadas.

Incentivar o processo de inovações é agir contra um modelo político que impõe, não raras vezes, a homogeneização como paradigma. As formas de avaliação externa, no contexto das políticas avaliativas da educação brasileira, têm sido um fator de retração da inovação, pois, em seus princípios, defendem e implementam um modelo único de qualidade sem, ao menos, discutí-lo na sua condição e contexto.

A crítica a esse modelo nem sempre tem encontrado energias capazes de fazer vigorar uma perspectiva emancipatória. As preocupações decorrentes dessa dimensão imposta estimula questionamentos: Que saberes precisam ser mobilizados nos professores para que a visão crítica dos processos regulatórios redunde em movimentos de resistência, em diferentes campos e manifestações? Como tomar essa realidade como ponto de referência para uma discussão mais sistematizada no interior da escola e da universidade? Como os processos de formação de professores estão enfrentando a problemática de uma avaliação regulatória que tende a imobilizar a inovação? Há espaços para a continuidade de iniciativas emancipatórias, contra a corrente dominante? Como elas se constituem?

Ainda que pareça ingênua a direção, a resposta à última questão será sempre positiva. O homem é por natureza inventivo e carrega a possibilidade da contradição. Sua capacidade inventiva é inesgotável e a possibilidade de uma energia emancipatória está sempre presente na educação que, necessariamente, numa inspiração freireana, precisa estar prenhe de esperança.

Tratar a inovação como ruptura epistemológica é dar-lhe uma dimensão emancipatória. Não numa perspectiva de negação da história, mas tentando partir desta para fazer avançar o processo de mudança, assumindo a fluidez das fronteiras que se estabelecem entre os paradigmas em competição. Para Santos, esses podem se tornar líquidos e navegáveis, numa cabotagem que resignifica subjetividades e, por essa razão, altera experiências.

Esta reflexão quer ser um agente analítico de compreensão das políticas educativas atuais mas, também, uma forma de concentrar energias para a resistência. Quer se alinhar a outros movimentos que reforcem a afirmativa de Santos de que a subjetividade 
emergente é uma subjetividade do sul. Ao fazer essa afirmativa o autor recupera analogicamente e se contrapõe à idéia eurocêntrica, que afirma o entendimento de que o rumo certo está no norte, de onde vem o uso corriqueiro da expressão nortear como sinônimo de colocar no prumo, dar um sentido adequado. Reconhecer o sul, no contexto do hemisfério, como energia inovadora, é estar disposto a legitimar formas alternativas de conhecimento bem como ousar andar na subjetividade da fronteira.

$\mathrm{Na}$ transição paradigmática

a subjetividade navega por cabotagem, guiando-se hora pelo paradigma
dominante, ora pelo paradigma emergente. E, se é verdade que o seu
objetivo último é aproximar-se tanto quanto possível do paradigma
emergente, ele sabe que só ziguezagueando lá poderá chegar e que, mais
do que uma vez, será o paradigma dominante a continuar a guiá-lo.
Cabotando assim, ao longo da transição paradigmática, a subjetividade de
fronteira sabe que navega num vazio cujo significado é preenchido,
pedaço a pedaço, pelos limites que ela vai vislumbrando, ora próximos, ora
longínquos. (Santos, 2002, p.335)

Nessa perspectiva é possível acreditar na condição de ruptura com a lógica dominante, inclusive dos processos de avaliação, que vem sendo aplicada ao longo do tempo e que encontrou um terreno fértil para seu revigoramento nos últimos anos, perante a reconfiguração da concepção de Estado, no mundo ocidental. Esta condição, entretanto, exige uma tessitura paciente de esforços e energias que envolvem a condição de escuta e a condição de espera, sem, entretanto, abrir mão da condição de análise crítica e reflexiva, que ajuda na compreensão dos acontecimentos e das teias que os envolvem.

Anima perceber que as pessoas, em geral, e os professores, em particular, são capazes de viver nos limites, submetidos à lógica predominante nos processos sociais e educativos, mas navegando na fronteira das práticas que ficam às margens. Talvez daí possa sair uma explicação para seus silêncios. Quem sabe são eles uma possibilidade de esperança.

Mencionar inovação, num contexto tão adverso, é fazer uma profissão de fé, que envolve a nossa condição de humanidade e a possibilidade de transformar os silêncios em possibilidades.

\section{Referências}

SANTOS, B. S. A crítica da razão indolente: da razão indolécício da experiência. São Paulo: Cortez, 2002.

TARDIF, M. Saberes docentes e formação profissional. Petrópolis: Vozes, 2002.

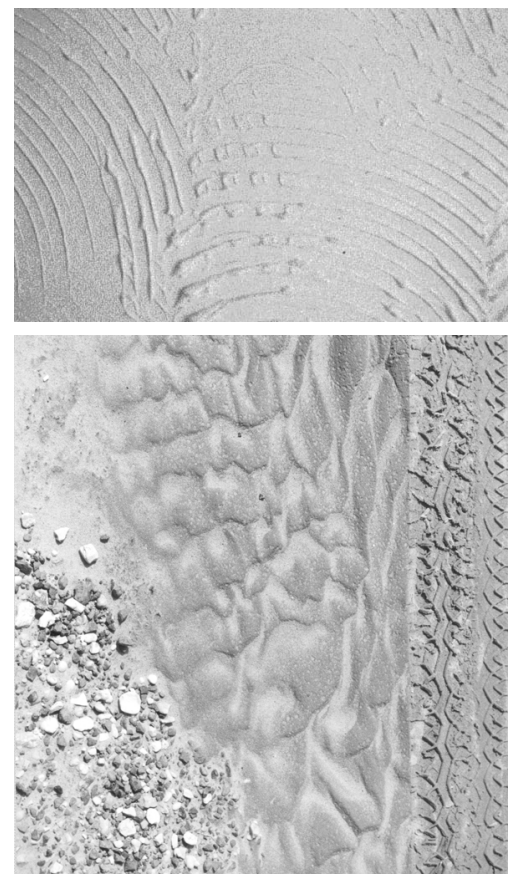

